Robertson, M., Viana da Fonseca, A., Ulrich, B., Coffin, J. (2017). "Characterization of unsaturated mine waste: a case history". Canadian Geotechnical Journal, Publ.on the web 02 June 2017 https://doi.org/10.1139/cgi-2017-0129

(๔ Copyright 2017 - Canadian Science Publishing)

\title{
Characterization of unsaturated mine waste: a case history
}

\author{
P.K. Robertson ${ }^{1}$, A. Viana da Fonseca ${ }^{2}$, B Ulrich ${ }^{3}$ and J. Coffin ${ }^{3}$
}

${ }^{1}$ Gregg Drilling \& Testing Inc., 2726 Walnut Ave.

Signal Hill, CA 90755

probertson@greggdrilling.com

${ }^{2}$ University of Porto (FEUP)

Portugal

${ }^{3}$ Knight Piesold Consulting

Denver, Colorado, USA

Feb. 2017 -Canadian Geotechnical Journal 
CGJ - Characterization of unsaturated mine waste: a case history 


\begin{abstract}
In the mining industry it is becoming relatively common for either crushed ore or filtered mine waste to be stacked to a significant height $(>100 \mathrm{~m})$ in a moist state with little compaction. The resulting deposit can be potentially loose and unsaturated. Characterization of these stacked deposits for stability under earthquake loading can be challenging due, in part, to the potentially unsaturated state. This paper presents a case history describing the characterization of stacked filtered tailings in South America. Cone penetration tests with pore pressure and seismic velocity measurements (SCPTu) were carried out along with selected drilling, sampling and laboratory testing. Compression $\left(\mathrm{V}_{\mathrm{p}}\right)$ and shear wave velocity $\left(\mathrm{V}_{\mathrm{s}}\right)$ profiles were obtained and compared to laboratory values on reconstituted saturated and unsaturated samples. The paper presents the results of the characterization and the interpretation.
\end{abstract}

Key words: Tailings, unsaturated, CPT, case history 


\section{Introduction}

In the mining industry it is becoming more common for either crushed ore or filtered mine waste to be stacked to a significant height $(>100 \mathrm{~m})$ in a moist state, often with little compaction. The resulting deposit can be potentially loose and unsaturated. Characterization of these stacked deposits for stability under earthquake loading can be challenging due, in part, to the potentially unsaturated state. This paper presents a case history describing the characterization for stacked filtered tailings in South America.

The tailings storage facility is composed of filtered tailings placed via conveyor and radial arm stacker within a valley. The materials have been placed in lifts of about 20 to $30 \mathrm{~m}$ thickness during previous mine operations with minimal compaction and currently have an approximate overall downstream slope of $4 \mathrm{H}: 1 \mathrm{~V}$ (horizontal to vertical). Lifts have been placed at slopes of approximately $1.5 \mathrm{H}: 1 \mathrm{~V}$ to $2.5 \mathrm{H}: 1 \mathrm{~V}$ with each lift offset by either 40 to $60 \mathrm{~m}$ to create benches.

At the time of the investigation the maximum height from toe to crest was about $200 \mathrm{~m}$ with a maximum thickness of tailings of about $125 \mathrm{~m}$, due to the sloping natural ground. The total surface area of the facility is about $282,000 \mathrm{~m}^{2}$ with an estimated volume of about 100 million tonnes. One of the main design issues is the stability of the tailings facility under seismic loading. Hence, detailed characterization is important to understand the behavior of the tailings under both static and seismic loading conditions. A major design issue is to determine if the tailings could experience any strength loss and hence, possible instability (i.e. flow liquefaction).

Given the dry climate in the region, the placement of the tailings in a moist loose state and the relatively low rate of irrigation, the tailings are expected to be predominately unsaturated. In unsaturated soils the voids are filled with a mixture of fluid and air resulting in suction forces. In general, unsaturated soils have a higher resistance to cyclic loading but may experience some strength loss if the degree of saturation is relatively high and the soils very loose (Grozic et al, 2000).

A review of the literature (e.g. Leroueil and Hight, 2003) on unsaturated soil behavior provides the following additional observations:

- Soil suctions increase the effective stresses $\left(\sigma^{\prime}\right)$ in the soil compared to saturated soils.

- Suction also increases the size of the yield surface for soils, such that unsaturated soils tend to behave more like an over-consolidated soil (i.e. respond inside the 
yield surface).

- The size of the yield surface is a function of the amount of suction (e.g. higher suction values produce larger yield surface and more dilatant response).

- Suction appears to move the Critical State Line (CSL) and is also a function of the amount of suction.

- The movement of the CSL produces an apparent 'cohesion' in terms of strength (due to the higher yield surface and CSL).

The objective of this paper is to present a summary of a recent tailings characterization program and to describe the interpretation and implications for design. The recent site investigation included seismic cone penetration tests with pore pressure measurements $(\mathrm{SCPTu})$. Based on accepted current practice there was a significant difference in the interpretation of soil behavior based on either cone resistance or shear wave velocity. Hence, much of this paper investigates and attempts to explain this difference.

\section{Site Investigation program}

Since the start of mine operations in 1990 there have been several geotechnical studies to characterize the tailings deposit. This paper will focus only on the most recent study that started in 2014 and was composed of SCPTu, drilling, sampling and installation of piezometers. Limited seismic profiling was also carried out using multichannel analysis of surface waves (MASW) at the downstream toe of the tailings facility. Laboratory testing was also carried on selected and representative reconstituted samples tested in either a saturated or unsaturated state.

Based on grain size distribution curves the tailings are classified as predominately silty sand to sandy silt with a mean grain size $\left(D_{50}\right)$ of about $0.065 \mathrm{~mm}$. The grain size distribution curve for the tested tailings is similar to other poorly graded silty tailings reported by Jefferies and Been (2006). The average specific gravity of the tailings is 2.73 and the tailings are predominately non-plastic.

The SCPTu program was carried out using a portable hydraulic ram mounted on to a drill rig. A total of 12 SCPTu locations were advanced in the tailings facility described in this paper. Compression $\left(\mathrm{V}_{\mathrm{p}}\right)$ and shear wave velocity $\left(\mathrm{V}_{\mathrm{s}}\right)$ measurements were made using a geophone in the $15 \mathrm{~cm}^{2}$ cross-sectional area cone using the down-hole method (e.g. Robertson et al, 1996). Pore pressures were measured in the $\mathrm{u}_{2}$ location behind the cone tip. Twenty-three (23) vibrating wire piezometers were also installed in cased boreholes at 6 locations to record and monitor the long-term piezometric pressures. At each 
location, several piezometers were installed at different depths in a nested array to monitor the piezometric pressures over time.

Figure 1 shows a typical SCPTu profile at the deepest section of the facility where the SCPTu profile extended to a depth of $96.6 \mathrm{~m}$. Figure 1 shows the profile of corrected cone tip resistance $\left(\mathrm{q}_{\mathrm{t}}\right)$, corrected for unequal end area (Campanella et al, 1982), sleeve friction $\left(\mathrm{f}_{\mathrm{s}}\right)$ and penetration pore pressure $\left(\mathrm{u}_{2}\right)$. Several zones required a drill-out due to the limited reaction capacity of the anchored drill rig and are identified in the profile as gaps in the SCPTu data. The SCPTu data suggest that the tailings are mostly composed of loose sandy silt with some zones that appear to have slightly higher fines content where some excess penetration pore pressures are recorded.

Dissipation tests were carried out at frequent depth intervals to estimate the equilibrium piezometric pressure $\left(\mathrm{u}_{\mathrm{o}}\right)$ at the time of the investigation. The time taken to monitor the dissipation of any excess penetration pore pressures varied from a few seconds up to 3600 s. The time required to reach $50 \%$ dissipation $\left(\mathrm{t}_{50}\right)$ varied from essentially zero (i.e. essentially drained penetration) up to $100 \mathrm{~s}$ with an average $t_{50}$ of about 50 s. In general, the equilibrium pore pressures measured by the SCPTu $\left(u_{o}\right)$ were close to zero over much of the profile. The very low piezometric profile was generally confirmed by the data from the vibrating wire piezometers monitored over a much longer time period. The maximum value for $\mathrm{u}_{\mathrm{o}}$ measured in the SCPTu profile shown in Figure 1 was about 50kPa at a depth of $84.3 \mathrm{~m}$.

Figure 2 shows the same SCPTu profile but in terms of normalized CPT parameters $\left(\mathrm{Q}_{\mathrm{tn}}\right.$, $F_{r}, B_{q}$ and $I_{c}$ ) suggested by Robertson (2009). The SCPTu data was normalized assuming an average total unit weight of $16 \mathrm{kN} / \mathrm{m}^{3}$ and a piezometric profile $\left(\mathrm{u}_{\mathrm{o}}\right)$ based on the dissipation tests and nearby piezometers. It is useful to note that the vertical effective stress near the base of the tailings is very high $\left(\sigma\right.$ ? $\left._{\mathrm{vo}}>15 \mathrm{~atm}\right)$, due to the predominately unsaturated nature of the materials (i.e. $\mathrm{u}_{\mathrm{o}} \sim 0$ ). The soil behavior type index $\left(\mathrm{I}_{\mathrm{c}}\right)$ is close to 2.6 over much of the profile suggesting that the soils are transitional in behavior between either more sand-like or more clay-like (Robertson, 2009). This is consistent with the measured grain size distribution of silty sand to sandy silt and the partial drainage conditions during CPT with average $t_{50}$ values close to 50s, that was suggested as the boundary between fully undrained cone penetration and partially drained penetration (DeJong and Randolph, 2014). Given the high overburden stresses with depth, the grain size distribution is expected to become slightly finer with depth due to some grain crushing. The relatively low average normalized cone resistance value $\left(\mathrm{Q}_{\mathrm{tn}} \sim\right.$ 20) suggests that the tailings would have a cyclic resistance ratio (CRR) of around 0.1 and would be expected to be generally contractive in shear at large strains (Robertson and Wride, 1998; Robertson, 2009). 
Figure 3 shows the same SCPTu profile (as shown in Figures 1 and 3) in terms of the measured seismic compression wave velocity $\left(\mathrm{V}_{\mathrm{p}}\right)$ and shear wave velocity $\left(\mathrm{V}_{\mathrm{s}}\right)$. The measured compression wave velocity $\left(\mathrm{V}_{\mathrm{p}}\right)$ varies from about $350 \mathrm{~m} / \mathrm{s}$ up to $1100 \mathrm{~m} / \mathrm{s}$, with values generally increasing with depth. The measured shear wave velocity $\left(\mathrm{V}_{\mathrm{s}}\right)$ varies from about $225 \mathrm{~m} / \mathrm{s}$ up to $560 \mathrm{~m} / \mathrm{s}$ with values increasing with depth, as shown on Figure 4. Since $V_{p}$ for most saturated soils is about $1500 \mathrm{~m} / \mathrm{s}$, the measured values confirm that the deposit is predominately unsaturated. Studies have shown that $\mathrm{V}_{\mathrm{p}}$ is very sensitive to degree of saturation and can show a significant drop below $1500 \mathrm{~m} / \mathrm{s}$ for a very small change in degree of saturation of 1 or $2 \%$ (Jamiolkowski, 2012). However, $\mathrm{V}_{\mathrm{p}}$ cannot be used to estimate degree of saturation since the value tends to be insensitive to degree of saturation below values of around 98\% (Jamiolkowski, 2012). The combined normalized CPT and $\mathrm{V}_{\mathrm{s}}$ data suggest that much of the tailings have little microstructure, i.e. very young and uncemented (Robertson, 2016).

Figure 4 shows the same SCPTu profile in terms of normalized shear wave velocity $\left(\mathrm{V}_{\mathrm{s} 1}\right)$, defined as follows:

$\mathrm{V}_{\mathrm{s} 1}=\mathrm{V}_{\mathrm{s}}\left(\mathrm{p}_{\mathrm{a}} /{\sigma^{\prime}}_{\mathrm{vo}}\right)^{0.25}$

Where $\mathrm{p}_{\mathrm{a}}=$ reference pressure $=100 \mathrm{kPa}$

$\sigma_{\text {vo }}^{\prime}=$ in-situ vertical effective stress

The vertical effective stress was based on assumed dry soil (i.e. no suction) with a soil unit weight of $16 \mathrm{kN} / \mathrm{m}^{3}$. The average normalized shear wave velocity is $225 \mathrm{~m} / \mathrm{s}$. Although accuracy is reduced with depth using the down-hole method, as reflected in the increased scatter with depth, the seismic measurements show a consistent trend of approximately constant normalized values with depth. The SCPTu measured shear wave velocity values also agree with the limited available MASW values. As will be shown later, the assumption of zero suction to normalize the CPT and seismic velocities is reasonable given the relatively small in-situ suction values compared to the very high total overburden stresses below a depth of about $10 \mathrm{~m}$. The high value of normalized shear wave velocity $\left(\mathrm{V}_{\mathrm{s} 1} \sim 225 \mathrm{~m} / \mathrm{s}\right)$ suggests that the tailings would have a CRR around 0.4 (Kayen et al, 2014) and would be expected to be generally dilative in shear at large strains (Robertson, 1995). Hence, there appears to be inconsistency in the interpretation of behavior under both cyclic and monotonic shear between the normalized cone resistance and the normalized shear wave velocity. This difference may, in part, be due to the lack of saturation and was investigated through laboratory testing. 


\section{Laboratory testing}

The tailings are derived from crushed Cenozoic volcanic and Triassic sedimentary rocks from the adjacent mine. The tailings are filtered and placed uncompacted to form a generally loose unsaturated deposit. Surface irrigation is carried out resulting in some fluid percolating through the tailings. Based on samples, the in-situ water content varies between 2 to $15 \%$ and the degree of saturation between 5 to $50 \%$, depending on depth, location and localized irrigation.

\section{Saturated samples}

Laboratory testing was carried out on reconstituted samples to identify critical state (CS) parameters. A series of isotropically consolidated drained and undrained triaxial tests were carried out on reconstituted samples with approximate dimensions of $72 \mathrm{~mm}$ diameter and $144 \mathrm{~mm}$ height prepared loose by moist tamping at an initial moisture content of about $11.5 \%$. Triaxial tests were conducted in axial compression until either critical state was reached or about $20 \%$ axial strain. The triaxial equipment was fitted with piezoelectric elements to measure both compression $\left(\mathrm{V}_{\mathrm{p}}\right)$ and shear wave velocity $\left(\mathrm{V}_{\mathrm{s}}\right)$. Testing was carried out on saturated samples that were saturated using a combined $\mathrm{CO}_{2}$ percolation and backpressure method. Saturation was achieved when a measured Skempton's pore pressure parameter B of 0.98 or higher was reached along with a measured compression wave velocity of about $1500 \mathrm{~m} / \mathrm{s}$. The saturation process was conducted under an effective confining stress of $10 \mathrm{kPa}$ according to Viana da Fonseca et al (2015). The saturation process causes a slight collapse of the very loose samples resulting in slightly lower void ratios during consolidation. During the consolidation and shearing phases, the seismic velocities $\left(V_{p}\right.$ and $\left.V_{s}\right)$ were measured using bender-extender elements, incorporated in the triaxial equipment. The interpretation of velocities was carried out in the time and frequency domain (e.g. Viana da Fonseca et al, 2009).

Table 1 shows a summary of the test program on the saturated samples in terms of void ratio $\left(\mathrm{e}_{\mathrm{c}}\right)$ and mean effective stress $\left(\mathrm{p}_{\mathrm{c}}^{\prime}\right)$ at end of consolidation and void ratio $\left(\mathrm{e}_{\mathrm{f}}\right)$, mean effective stress $\left(\mathrm{p}_{\mathrm{f}}^{\prime}\right)$, shear stress $\left(\mathrm{q}_{\mathrm{cs}}\right)$ and axial strain at end of shear or critical state $\left(\varepsilon_{\mathrm{cs}}\right)$. Table 2 shows a summary of the test program on the saturated samples in terms of the measured seismic velocities at end of consolidation.

Since sandy soils can be sensitive to small changes in void ratio (e), a series of three tests (tests 10,11 and 12 in Table 1) were carried out without bender-extender elements so that the samples could be frozen after shearing to accurately measure the final void ratio $\left(\mathrm{e}_{\mathrm{f}}\right)$, as suggested by Sladen and Handford (1987) with details in Soares and Viana da Fonseca (2016). Volume change during consolidation and shearing was measured using an automatic volume gauge with electronic displacement transducer. 
Figure 5 shows a summary of the triaxial test results on saturated samples in terms of void ratio (e) and effective mean stress (p') for end of consolidation and at Critical Sate (CS). The Critical State Line (CSL) is also identified as a locus of points at CS. The end-of-consolidation points represent an approximate isotropic limiting compression curve (LCC) for very loose saturated samples (e.g. Pestana and Whittle, 1995).

All the samples tested had very loose states at the end of consolidation relative to CS, with an average state parameter of around $\psi \sim+0.1$. The loose samples tested in undrained compression at effective confining stresses less than $200 \mathrm{kPa}$ showed complete strength loss with a shear stress at failure $\left(\mathrm{q}_{\mathrm{f}}\right)$ close to zero. All samples were contractive at large strains and either showed an increase in pore pressures when sheared undrained or compressive volumetric strains when sheared drained. The CSL appears to bend downward at mean effective stresses greater than about 500kPa. The CSL for the tested tailings is similar to other silty tailings reported by Jefferies and Been (2006), Bedin et al, (2012), Schnaid et al (2013) and Robertson (2016). Based on the tests in this study on saturated tailings the critical friction angle, $\mathrm{M}=1.34\left(\phi^{\prime}=33.5^{\circ}\right)$

Cunning et al (1995) had suggested a linear relationship between normalized shear wave velocity $\left(\mathrm{V}_{\mathrm{s} 1}\right)$ and void ratio (e) for young, uncemented sands and Figure 6 shows the measured relationship between $\mathrm{V}_{\mathrm{s} 1}$ and e for the end of consolidation conditions for the saturated tailings in this study. For these tailings in a saturated state the linear relationship, similar to that suggested by Cunning et al (1995), is:

$\mathrm{V}_{\mathrm{s} 1}=220-145 \mathrm{e} \quad(\mathrm{m} / \mathrm{s})$

Based on this relationship combined with Equation 1, it is possible to show contours of $\mathrm{V}_{\mathrm{s}}$ on the $\mathrm{e}-\mathrm{p}^{\prime}$ plot, as shown on Figure 7 compared to the measured CSL. Jefferies and Been (2006) have suggested that the separation between a dilative and contractive response at large strains occurs at a State Parameter of about $\psi=-0.05$. At a mean effective reference stress of $100 \mathrm{kPa}$, this would represent a consolidated void ratio of about $\mathrm{e}_{\mathrm{c}}=0.59$. Based on Figure 6 , this contractive-dilative boundary can be represented by $\mathrm{V}_{\mathrm{s} 1}=135 \mathrm{~m} / \mathrm{s}$. This is similar to the values suggested by Cunning et al (1995), of 130 to $150 \mathrm{~m} / \mathrm{s}$ for a range of saturated young, uncemented clean sands. The laboratory data also shows that when $\mathrm{V}_{\mathrm{s} 1}<115 \mathrm{~m} / \mathrm{s}$ (i.e. when $\mathrm{e}_{\mathrm{c}}>0.72$ ) the saturated tailings samples in this study will essentially collapse (i.e. $\mathrm{q}_{\mathrm{cs}} \sim 0$ ) in undrained shear.

Based on the laboratory tests on saturated samples, the average measured in-situ normalized shear wave velocity of $225 \mathrm{~m} / \mathrm{s}$ suggest that the tailings would be expected to be strongly dilative at large strains, if saturated. Hence, there is a difference between 
predicted behavior under saturated conditions based on either CPT penetration resistance, that suggest a contractive behavior, or shear wave velocity, that suggests a dilative behavior at large strains. However, the measured in-situ compression wave velocity values and limited samples confirm that the tailings are predominately unsaturated and in-situ suctions may influence the behavior and resulting interpretation. To investigate this further, a series of laboratory tests were preformed on similar reconstituted samples but tested unsaturated.

\section{Soil Water Characteristic Curve (SWCC)}

For unsaturated soils, the suction can be represented by a soil-water characteristic curve (SWCC) that defines the relationship between soil matric suction $\left(\mathrm{u}_{\mathrm{a}}-\mathrm{u}_{\mathrm{w}}\right)$ and degree of saturation, $\mathrm{S}(\%)$. The SWCC is also a function of grain size distribution, with larger suctions in more fine-grained soils.

Suction tests to determine the SWCC were performed in two Richards' chambers (one for lower pressures and one for high pressures). Circular specimens were molded inside steel rings, using the moist tamping technique, with $11.5 \%$ water content and initial void ratio of 1.2 (the same void ratio values used for the triaxial tests). The specimens were placed on a porous stone inside the chamber and saturated. The samples stayed inside the chamber at constant differential pressure (i.e. suction) for 7 days, then the water content determined for the specific pressure (suction). This process was restarted for the different pressures (suctions) applied, always starting from the same initial water content and initial void ratio. For each pressure, 4 specimens were molded and the values considered are the mean of the four values obtained. The suction pressures were 4, 8, 20, 32, 60, 100, 200, 400, 600 and 700kPa. Figure 8 shows the resulting SWCC in terms of degree of saturation (S) versus suction (s). The measured SWCC is consistent with other silty sands to sandy silts (e.g. Leroueil and Hight, 2003). The in-situ degree of saturation varies between 5 to $50 \%$, which indicates that the in-situ suctions range from around $5 \mathrm{kPa}$ to $300 \mathrm{kPa}$.

Soil suctions increase the effective stresses $\left(\sigma^{\prime}\right)$ in the soil compared to saturated soils, as follows.

$$
\begin{aligned}
& \sigma^{\prime}=\left(\sigma-\mathrm{u}_{\mathrm{a}}\right)+\chi\left(\mathrm{u}_{\mathrm{a}}-\mathrm{u}_{\mathrm{w}}\right) \\
& \text { where } \quad \sigma=\text { total stress } \\
& \mathrm{u}_{\mathrm{a}}=\text { pore-air pressure } \\
& \mathrm{u}_{\mathrm{w}}=\text { soil-water pressure } \\
& \left(\mathrm{u}_{\mathrm{a}}-\mathrm{u}_{\mathrm{w}}\right)=\text { matric suction }=\mathrm{s}
\end{aligned}
$$




$$
\begin{aligned}
& \left(\sigma-u_{a}\right)=\text { net total stress } \\
& \chi=\text { effective stress parameter which has a value of } 1 \text { for saturated soils } \\
& \text { and } 0 \text { for dry soil }
\end{aligned}
$$

The increase in effective stress increases the strength and stiffness of an unsaturated soil. Hence, unsaturated soils tend to be stronger and stiffer than identical saturated soils. The effective stress parameter $(\chi)$ varies with degree of saturation (S). Several approaches have been introduced for estimating the $\chi$ parameter, such as utilizing the air entry value (e.g. Kalili and Khabbaz, 1998; Kalili et al, 2004), and the effective degree of saturation (e.g. Lu and Like, 2006; Lu et al, 2010). For practical purposes it is common to assume that the variation of the $\chi$ parameter is assumed to be linear with the degree of saturation, $\mathrm{S}$ (i.e. from 0 to 1 ).

\section{Unsaturated samples with known suction}

A series of isotropically consolidated triaxial compression tests were performed on similar reconstituted samples of tailings under different known suction conditions. Sample preparation was identical for the saturated samples but strain and volume changes were measured using axial and radial transducers (Hall-effect calipers). As tests were performed under unsaturated conditions, there was no percolation and saturation phase. Two tests were carried out using a triaxial cell (TX) that can control the suction using a high air entry porous stone. Five tests were carried out using a Bishop-Wesley cell (BW) modified to measure seismic velocities using bender elements under constant-watercontent conditions with a suction probe to measure suction within the sample. In the Bishop-Wesley cell the suction cannot be imposed so, in order to have the required suction, the samples were molded with specific initial water content, corresponding to the desired suction according to the measured SWCC. The moisture content was checked before and after the test and did not vary significantly. The suction was also measured using a suction probe and confirmed agreement between the expected suction based on the SWCC and measured suctions. According to the SWCC, a suction of $20 \mathrm{kPa}$ corresponds to water content of $11.5 \%$ and a suction of $200 \mathrm{kPa}$ corresponds to water content of $4.0 \%$. The tests performed are presented in Table 3, where the type of cell, total confining pressure and suction are summarized along with values of the void ratio and water content measured before and after testing.

A challenge when testing unsaturated samples is the ability to track volume changes. Radial (Hall-effect) calipers were used to track changes in sample diameter. Since the samples bulged during shearing, the sample volume change was based on an assumed

parabolic shape of the deformed specimen. The samples were contractive and strain hardening during shear although the volumetric strains were generally small, with changes in void ratio generally less than 0.1 . The contractive behavior was primarily due to compression of air voids during shear. 
Table 4 presents a summary of the measured seismic velocities on the unsaturated samples at the end of consolidation. An additional test (T9-600S20) was performed on a similar unsaturated sample to measure seismic wave velocities at different total consolidation stresses with a controlled suction of $20 \mathrm{kPa}$. The velocity measurements on unsaturated samples with known suction provide an opportunity to determine the relationship between normalized shear wave velocity $\left(\mathrm{V}_{\mathrm{s} 1}\right)$ and void ratio for unsaturated samples based on the effective stress values that incorporate suction using equation 3 .

The in-situ degree of saturation of the tailings is in the range of 5 to $50 \%$. The average in-situ degree of saturation is around 10 to $20 \%$ that would suggest an average in-situ suction of around 50 to $100 \mathrm{kPa}$ based on the SWCC. Based on a range of methods the $\chi$ parameter would vary from 0.1 to 0.2 , for $S$ from 0.1 to 0.2 . An average $\chi$ parameter of 0.1 was applied, although the results are not overly sensitive to the exact value selected based on number of different methods. The results of normalized shear wave velocity versus void ratio as a function of suction is shown in Figure 9 that shows that $V_{s 1}$ increases significantly with suction. This increase appears to be primarily due to suction hardening effects and not the change in effective stress from the suction. The suction hardening effects are similar to interparticle cementation where suction hardening is an isotropic hardening phenomenon that controls the size of the yield surface in additional to plastic volumetric strains, and therefore the location of the CSL (Loret and Khalili, 2002, Arroyo et al, 2013). The change in small strain stiffness reflected by $\mathrm{V}_{\mathrm{s} 1}$ is significant for a small amount of suction. For example $\mathrm{V}_{\mathrm{s} 1}$ increases by $58 \%$ with only $20 \mathrm{kPa}$ suction that is equivalent to an approximately $150 \%$ increase in small strain shear modulus, $G_{0}$ for a small change in effective stress.

A summary of the triaxial tests in terms of the critical state line (CSL) for both saturated and unsaturated samples is shown in Figure 10. The tests on the unsaturated tailings showed that the CSL was located at higher values of void ratio (for similar confining stress) compared to the saturated samples. The CSL for unsaturated samples appears to be independent of the magnitude of the suction. Others (e.g. Fern et al, 2016) have reported no change in CSL due to suction hardening in clean sands whereas others (e.g. Russell and Khalili, 2006) reported a significant change in CSL in clays. It appears that the influence of suction hardening on small strain stiffness and the location of the CSL maybe a function of grain size distribution, where more fine-grained soils show a larger influence due to suction hardening. 


\section{Discussion}

As stated earlier, the in-situ degree of saturation of the tailings is in the range of 5 to $50 \%$ with an average value around 10 to $20 \%$. This would suggest an average in-situ suction of around 50 to $100 \mathrm{kPa}$ based on the SWCC. Based on a range of methods the $\chi$ parameter would vary from 0.1 to 0.2 , for $S$ from 0.1 to 0.2 . Hence, the additional effective stress due to suction $(\chi s)$ is only around $10 \mathrm{kPa}$. Given the significant depth profile of the tailings with resulting high total overburden stress, the additional effective stress from suction is very small at depths greater than around $10 \mathrm{~m}$. Hence, any error in calculated in-situ vertical effective stress ignoring suction is small for depth greater than $10 \mathrm{~m}$.

Figure 9 shows that the large change in $\mathrm{V}_{\mathrm{s} 1}$ when the soil is unsaturated is not due to the small change in effective stress but due to suction hardening effects and that the hardening itself appears to be a function of suction. The suction hardening is similar to cementation in that the small strain stiffness (via shear wave velocity) is not controlled

primarily by effective stress. Cementation and suction hardening appears to reinforce the links between particles, and increases the small strain stiffness, even at the same void ratio. It appears that because shear wave velocity is a small strain measurement, it is sensitive to suction hardening and captures the correct in-situ unsaturated behavior. The cone resistance is a large strain measurement that can destroy the beneficial effects of suction hardening and be insensitive to the unsaturated in-situ behavior. This may explain why the normalized cone resistance values are relatively small compared to the relatively higher normalized shear wave velocity values. The process of cone penetration may decrease the beneficial effects of suction on the yield surface and CSL, which may explain the perceived looser state from the CPT. It appears that the shear wave velocity is more sensitive to the suction hardening from lack of saturation whereas the cone resistance destroys the beneficial effects of suction hardening and provides a measure of the soil behavior closer to what would exist if the soil became fully saturated when the suction hardening effects become removed.

The in-situ normalized shear wave velocity values are predominately between 200 and $250 \mathrm{~m} / \mathrm{s}$. These values are not significantly changed when accounting for in-situ suctions from 20 to $200 \mathrm{kPa}$. Taking this range of in-situ suction values combined with the measured normalized shear wave velocity values it is possible to estimate the in-situ void ratio using Figure 9. Using this approach, the estimated in-situ void ratio is between 0.58 and 0.72 , as shown schematically in Figure 9. The average in-situ void ratio is estimated to be about 0.65 . It is interesting to note that the seismic velocity values (both $V_{s}$ and $V_{p}$ ) measured on the unsaturated sample with a void ratio of 0.65 (Test T9-600S20) are close to those measured in-situ at similar values of total overburden stress. 
Taking this range of estimated void ratio combined with the estimated range of in-situ mean effective stress it is possible to plot the in-situ state relative to the various CSL's, as shown schematically in Figure 11. Based on Figure 11, the in-situ void ratio values of between 0.58 and 0.72 for in-situ effective stress levels of between 100 to $1000 \mathrm{kPa}$ suggest that the soils are on the dilative side of the unsaturated CSL. Hence, based on the in-situ shear wave velocity measurements and laboratory testing, the in-situ tailings are expected to behave in a dilative manner in shear at large strains when unsaturated. If the soils were to become saturated, the range of estimate in-situ void ratio and stress levels would suggest that the soils could be more contractive, as shown schematically in Figure 11. However, it is uncertain what effect suction hardening may have on the soil behavior after saturation, although the CPT data suggests that almost all beneficial effects from the suction hardening are destroyed at large strains and likely also destroyed when the soil becomes $100 \%$ saturated. This difference is consistent with the initial interpretation, where the shear wave velocity data suggested a dilative behavior and high CRR compared to the contractive behavior and low CRR based on the cone resistance. It would appear that the shear wave velocity data are predicting the in-situ behavior of the tailings when unsaturated and the cone resistance data are predicting the in-situ behavior if the soil becomes saturated and the benefits of suction hardening are removed.

These average suction values can have a significant influence on the strength of the material at very shallow depth $(<5 \mathrm{~m})$, where the increase in effective stress relative to the total confining stress is high. However, the CPT data at depth is marginally affected by soil suction in terms of the effective stress. When the degree of saturation is relatively high the process of cone penetration tends to compress the material in front of the cone and tends to push the material toward $100 \%$ saturation. This can sometimes be identified in the CPT data where there are positive excess pore pressures during penetration in more fine-grained soils that appear to be unsaturated based on measured compression wave velocities. In the deeper CPT's there are sections with positive excess pore pressures during the CPT that may reflect slightly higher degrees of saturation, consistent with a somewhat finer grain size of the tailings. Although the CPT data suggest zones of higher saturation, the measured compression wave velocity data $\left(\mathrm{V}_{\mathrm{p}}\right)$ suggests that saturation is less than $100 \%$. 


\section{Summary and Conclusions}

A detailed characterization was carried out on loose unsaturated mine tailings using SCPTu combined with laboratory testing. The tailings are predominately young, uncemented silty sand to sandy silt that are essentially normally consolidated. Using conventional interpretation methods there is a significant difference between the expected static and cyclic behavior of the tailings based on either cone resistance or shear wave velocity data. A laboratory test program was carried out on reconstituted loose samples that were either saturated or unsaturated to aid in the interpretation. The Critical State Line (CSL) was determined for saturated samples as well as the relationship between normalized shear wave velocity and void ratio. A series of tests was also carried on similar reconstituted samples but in an unsaturated state to determine the change in CSL location and the change in relationship between normalized shear wave velocity and void ratio. This testing showed that there was a significant change in normalized shear wave velocity for a relatively small change in suction and that this change was not due to the small change in effective stress but due to suction hardening and that the hardening itself appears to be a function of the magnitude of suction. The suction hardening is similar to cementation in that the small strain stiffness (via shear wave velocity) is not controlled primarily by effective stress. It appears that because shear wave velocity is a small strain measurement, it is sensitive to suction hardening and appears to capture the correct in-situ unsaturated behavior. The cone resistance is a large strain measurement that can destroy the beneficial effects of suction hardening and appears to be insensitive to the unsaturated in-situ behavior but may capture the correct behavior after the beneficial effects of suction are removed if the soil becomes saturated.

\section{Acknowledgments}

\section{REFERENCES}

Jamiolkowski, M., Leroueil, S. \& Lo Presti, D.C.F. 1991. Theme Lecture: Design parameters, from theory to practice. Proc. Geo-Coast '91, Yokohama. Vol. 2: 877-917.

Loret B, Khalili N. An effective stress elastic-plastic model for unsaturated porous media. Mechanics of Materials 2002; 34:97-116. 
CGJ - Characterization of unsaturated mine waste: a case history

Table 1 Summary of isotropically consolidated triaxial compression tests on saturated reconstituted samples

\begin{tabular}{|c|c|c|c|c|c|c|c|}
\hline \multirow[t]{2}{*}{ Test } & \multirow{2}{*}{$\begin{array}{l}\text { Test } \\
\text { Type }\end{array}$} & \multicolumn{2}{|c|}{$\begin{array}{c}\text { End of } \\
\text { Consolidation }\end{array}$} & \multicolumn{4}{|c|}{ End of shearing or Critical State } \\
\hline & & $e_{c}$ & $\begin{array}{l}\mathrm{p}_{\mathrm{c}}^{\prime} \\
\mathrm{kPa}\end{array}$ & $\mathrm{e}_{\mathrm{f}}$ & $\begin{array}{l}\mathrm{p}_{\mathrm{cs}}^{\prime} \\
\mathrm{kPa}\end{array}$ & $\begin{array}{c}\mathrm{q}_{\mathrm{cs}} \\
\mathrm{kPa}\end{array}$ & $\begin{array}{c}\varepsilon_{\mathrm{cs}} \\
\%\end{array}$ \\
\hline 1 & CIU & 0.80 & 20 & 0.80 & 0 & 0 & 1.92 \\
\hline 2 & CIU & 0.76 & 60 & 0.76 & 0 & 0 & 2.09 \\
\hline 3 & CIU & 0.75 & 100 & 0.75 & 0 & 0 & 4.89 \\
\hline 4 & CIU & 0.71 & 199 & 0.71 & 2 & 0 & 5.95 \\
\hline 5 & CIU & 0.67 & 601 & 0.67 & 10 & 10 & 23.35 \\
\hline 6 & $\overline{\mathrm{CIU}}$ & 0.63 & 1200 & 0.63 & 94 & 127 & 4.30 \\
\hline 7 & CID & 0.79 & 20 & 0.66 & 33 & 43 & 27.61 \\
\hline 8 & CID & 0.77 & 59 & 0.64 & 109 & 150 & 42.12 \\
\hline 9 & CID & 0.77 & 101 & 0.64 & 186 & 257 & 28.61 \\
\hline 10 & CIU* & 0.77 & 20 & 0.77 & 0 & 0 & 2.5 \\
\hline 11 & CIU* & 0.74 & 100 & 0.74 & 0 & 0 & 11.10 \\
\hline 12 & CID* & 0.67 & 601 & 0.54 & 1083 & 1455 & 45.2 \\
\hline \multicolumn{8}{|c|}{ CIU Isotropically consolidated undrained compression } \\
\hline$C I D$ & \multicolumn{7}{|c|}{ Isotropically consolidated drained compression } \\
\hline$*$ & \multicolumn{7}{|c|}{ No seismic measurements and samples frozen to determine void ratio } \\
\hline
\end{tabular}

Table 2 Summary of seismic velocity measurements in isotropically consolidated triaxial compression tests on saturated reconstituted samples

\begin{tabular}{|c|c|c|c|c|c|}
\hline \multirow{2}{*}{ Test } & \multirow{2}{*}{$\begin{array}{c}\text { Test } \\
\text { Type }\end{array}$} & \multicolumn{4}{|c|}{ End of Consolidation } \\
\cline { 3 - 6 } & $\mathrm{e}_{\mathrm{c}}$ & $\begin{array}{c}\mathrm{p}^{\prime}{ }_{\mathrm{c}} \\
\mathrm{kPa}\end{array}$ & $\begin{array}{c}\mathrm{V}_{\mathrm{p}} \\
\mathrm{m} / \mathrm{s}\end{array}$ & $\begin{array}{c}\mathrm{V}_{\mathrm{s}} \\
\mathrm{m} / \mathrm{s}\end{array}$ \\
\hline 1 & CIU & 0.80 & 20 & 1483 & 64 \\
\hline 2 & CIU & 0.76 & 60 & 1493 & 94 \\
\hline 3 & CIU & 0.75 & 100 & 1480 & 111 \\
\hline 4 & CIU & 0.71 & 199 & 1513 & 138 \\
\hline 5 & CIU & 0.67 & 601 & 1523 & 200 \\
\hline 6 & CIU & 0.63 & 1200 & 1587 & 232 \\
\hline 7 & CID & 0.79 & 20 & 1527 & 72 \\
\hline 8 & CID & 0.77 & 59 & 1226 & 99 \\
\hline 9 & CID & 0.77 & 101 & 1534 & 112 \\
\hline
\end{tabular}


Table 3 Summary of isotropically consolidated drained triaxial compression tests on unsaturated reconstituted samples with known suction

\begin{tabular}{|c|c|c|c|c|c|}
\hline \multirow{2}{*}{ Test } & $\begin{array}{c}\text { Confining } \\
\text { Stress } \\
\mathrm{p}_{\mathrm{c}}\end{array}$ & $\begin{array}{c}\text { Suction } \\
\mathrm{s}\end{array}$ & $\begin{array}{c}\text { Initial } \\
\text { void } \\
\text { ratio } \\
\mathrm{e}_{0}\end{array}$ & $\begin{array}{c}\text { Initial } \\
\text { water } \\
\text { content } \\
\mathrm{w}_{0}\end{array}$ & $\begin{array}{c}\text { Final } \\
\text { water } \\
\text { content } \\
\mathrm{w}_{\mathrm{f}}\end{array}$ \\
\cline { 2 - 6 } & $(\mathrm{kPa})$ & $(\mathrm{kPa})$ & & $\%$ & $\%$ \\
\hline T1-50S20TX & 50 & 20 & 0.94 & 11.72 & 9.95 \\
\hline T2-600S20TX & 600 & 20 & 0.83 & 15.27 & 9.70 \\
\hline T3-600S20BW & 600 & 20 & 0.81 & 11.15 & 12.30 \\
\hline T4-600S200BW & 600 & 200 & 0.86 & 3.80 & 3.79 \\
\hline T5-50S200BW & 50 & 200 & 0.86 & 3.90 & 3.92 \\
\hline T6-400S200BW & 400 & 200 & 0.85 & 4.01 & 3.94 \\
\hline T7-200S20BW & 200 & 20 & 0.85 & 11.36 & 11.30 \\
\hline
\end{tabular}

Table 4 Summary of seismic velocities measured on unsaturated samples with controlled suction values

\begin{tabular}{|c|c|c|c|c|c|c|}
\hline \multirow[t]{2}{*}{ Test } & \multirow{2}{*}{$\begin{array}{c}\text { Total } \\
\text { confining } \\
\begin{array}{c}\text { Stress } \\
\mathrm{p}_{\mathrm{c}}\end{array} \\
(\mathrm{kPa})\end{array}$} & \multirow{2}{*}{$\begin{array}{c}\text { Suction } \\
\text { s } \\
(\mathrm{kPa})\end{array}$} & \multirow[t]{2}{*}{$\begin{array}{c}\text { Void } \\
\text { ratio, e }\end{array}$} & \multirow{2}{*}{ 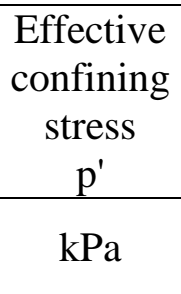 } & \multicolumn{2}{|c|}{$\begin{array}{c}\text { Seismic velocities } \\
\text { at end of } \\
\text { consolidation }\end{array}$} \\
\hline & & & & & $\begin{array}{c}V_{P} \\
(\mathrm{~m} / \mathrm{s})\end{array}$ & $\begin{array}{c}\mathrm{V}_{\mathrm{S}} \\
(\mathrm{m} / \mathrm{s})\end{array}$ \\
\hline T4-600S200 & 600 & 200 & 0.86 & 620 & 669 & 328 \\
\hline T5-50S20 & 50 & 200 & 0.86 & 70 & 460 & 192 \\
\hline T6-400S200 & 400 & 200 & 0.85 & 420 & 528 & 316 \\
\hline T7-200S20 & 200 & 20 & 0.85 & 202 & 550 & 211 \\
\hline \multirow{4}{*}{ T9-600S20 } & 50 & \multirow{4}{*}{20} & 0.674 & 52 & 736 & 178 \\
\hline & 200 & & 0.653 & 202 & 738 & 234 \\
\hline & 400 & & 0.635 & 402 & 728 & 275 \\
\hline & 600 & & 0.624 & 602 & 745 & 299 \\
\hline
\end{tabular}




\section{List of Figures}

Figure 1 Typical SCPTu profile showing basic CPTu parameters $\left(\mathrm{q}_{\mathrm{t}}, \mathrm{f}_{\mathrm{s}}, \mathrm{u}_{2}\right)$

Figure 2 Normalized CPT profile showing normalized parameters $\left(\mathrm{Q}_{\mathrm{tn}}, \mathrm{F}_{\mathrm{r}}, \mathrm{B}_{\mathrm{q}}, \mathrm{I}_{\mathrm{c}}\right)$

Figure 3 Typical seismic velocity profile in terms of compression $\left(\mathrm{V}_{\mathrm{p}}\right)$ and shear wave velocity $\left(\mathrm{V}_{\mathrm{s}}\right)$ measured using SCPTu.

Figure 4 Typical normalized shear wave velocity, $\mathrm{V}_{\mathrm{s} 1}$

Figure 5 Summary of isotropically consolidated triaxial compression tests on saturated reconstituted tailings samples showing Critical State Line (CSL) and Limiting compression curve.

Figure 6 Normalized shear wave velocity $\left(\mathrm{V}_{\mathrm{s} 1}\right)$ as a function of void ratio at the end of consolidation $\left(\mathrm{e}_{\mathrm{c}}\right)$ for saturated samples

Figure 7 Summary of isotropically consolidated triaxial compression tests on saturated reconstituted tailings samples with contours of shear wave velocity $\left(\mathrm{V}_{\mathrm{s}}\right)$

Figure 8 SWCC in terms of degree of saturation versus matric suction for silty tailings

Figure 9 Normalized shear wave velocity $\left(\mathrm{V}_{\mathrm{s} 1}\right)$ as a function of void ratio at the end of consolidation $\left(e_{c}\right)$ for saturated $(s=0)$ and unsaturated samples with suction of $\mathrm{s}=20$ and $200 \mathrm{kPa}$ of silty tailings

Figure 10 Critical State Line (CSL) for both saturated $(\mathrm{s}=0)$ and unsaturated samples ( $\mathrm{s}=20$ and $200 \mathrm{kPa}$ ) of silty tailings

Figure 11 Critical State Line (CSL) for both saturated $(s=0)$ and unsaturated samples ( $\mathrm{s}=20$ and $200 \mathrm{kPa}$ ) of silty tailings showing estimate range of in-situ void ratio and effective stress levels based on in-situ shear wave velocity measurements and laboratory tests on unsaturated samples 
CGJ - Characterization of unsaturated mine waste: a case history
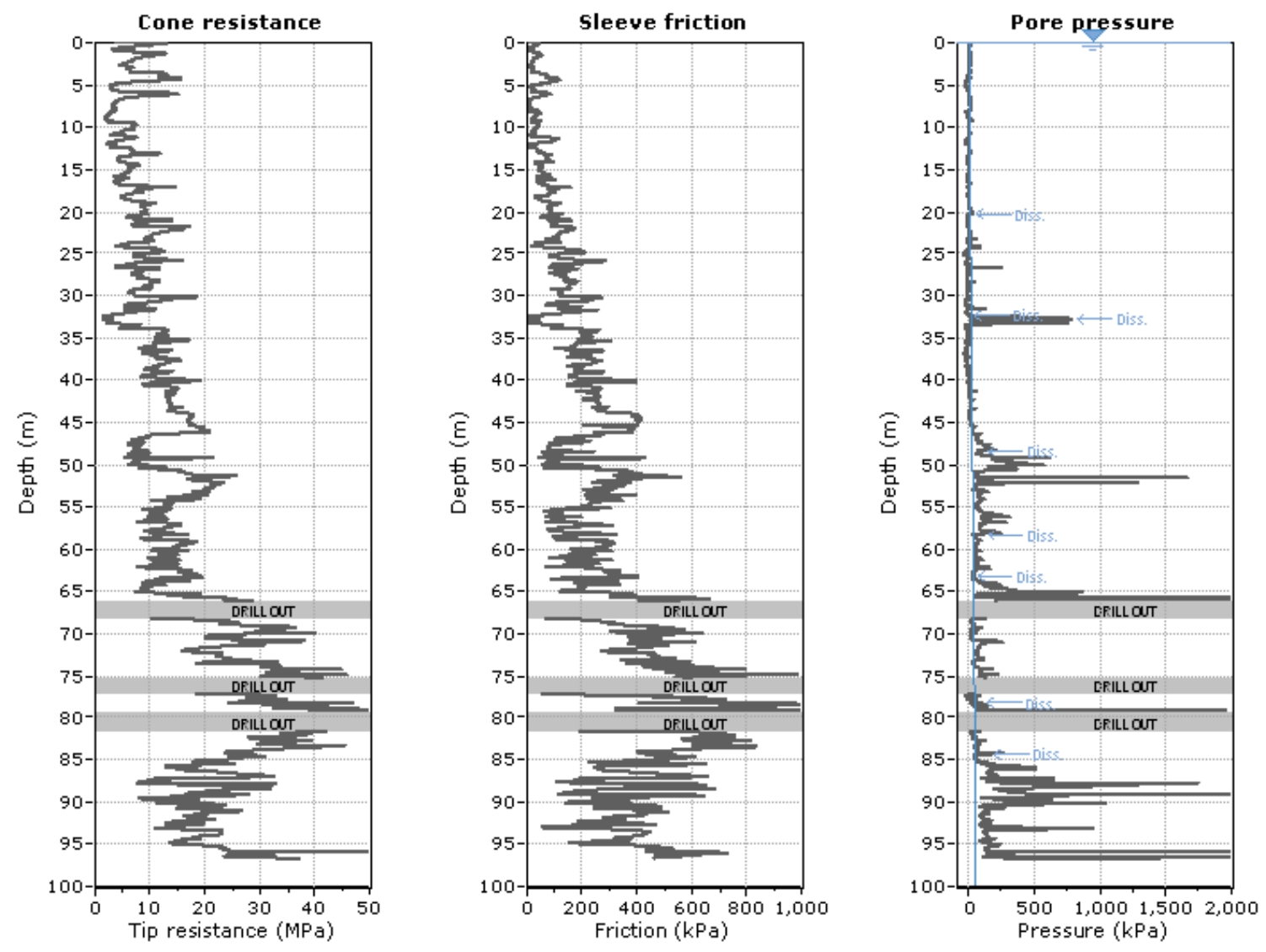

Figure 1 Typical SCPTu profile showing basic CPTu parameters $\left(\mathrm{q}_{\mathrm{t}}, \mathrm{f}_{\mathrm{s}}, \mathrm{u}_{2}\right)$ 
CGJ - Characterization of unsaturated mine waste: a case history
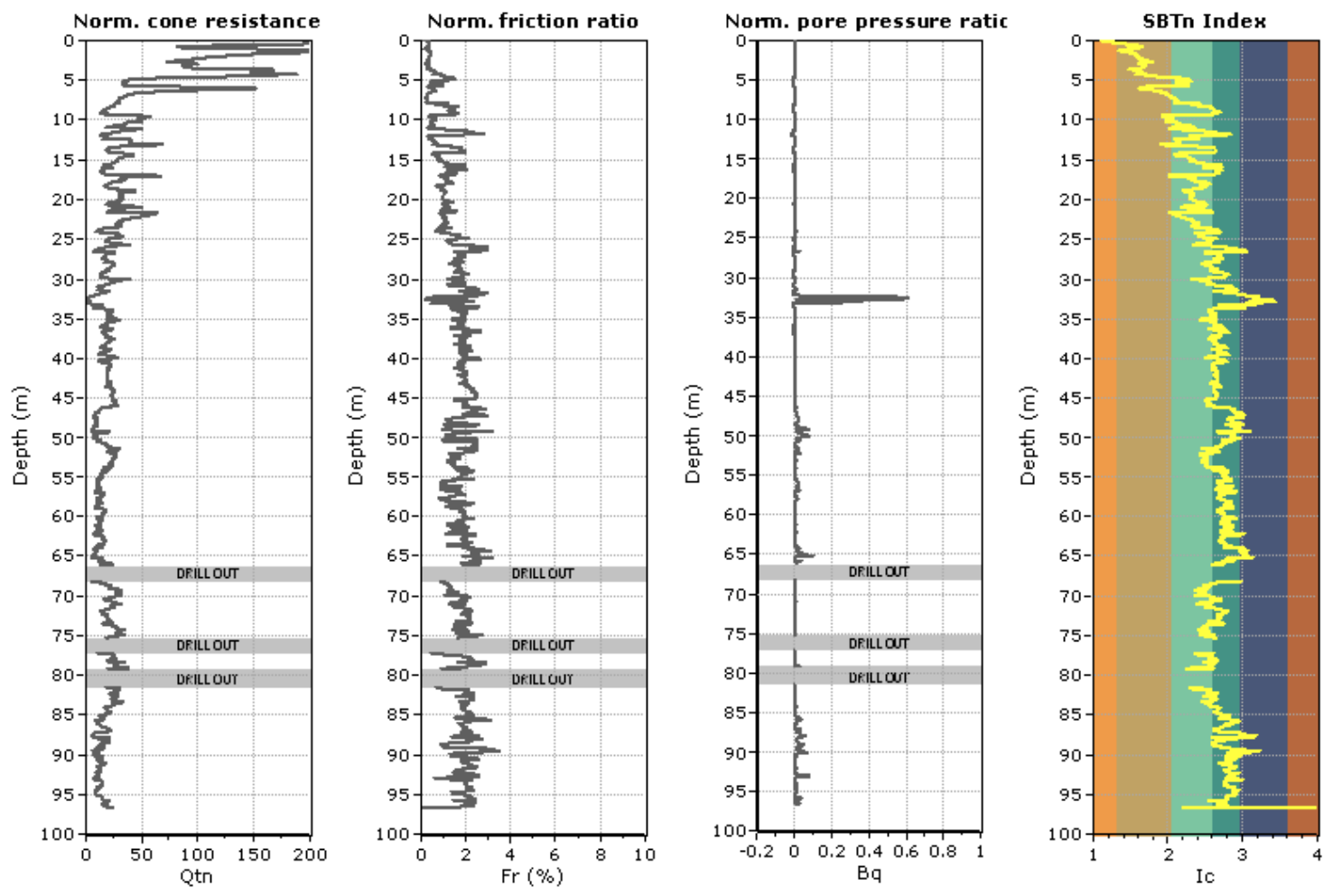

Figure 2 Normalized CPT profile showing normalized parameters $\left(\mathrm{Q}_{\mathrm{t}}, \mathrm{F}_{\mathrm{r}}, \mathrm{B}_{\mathrm{q}}, \mathrm{I}_{\mathrm{c}}\right)$ 


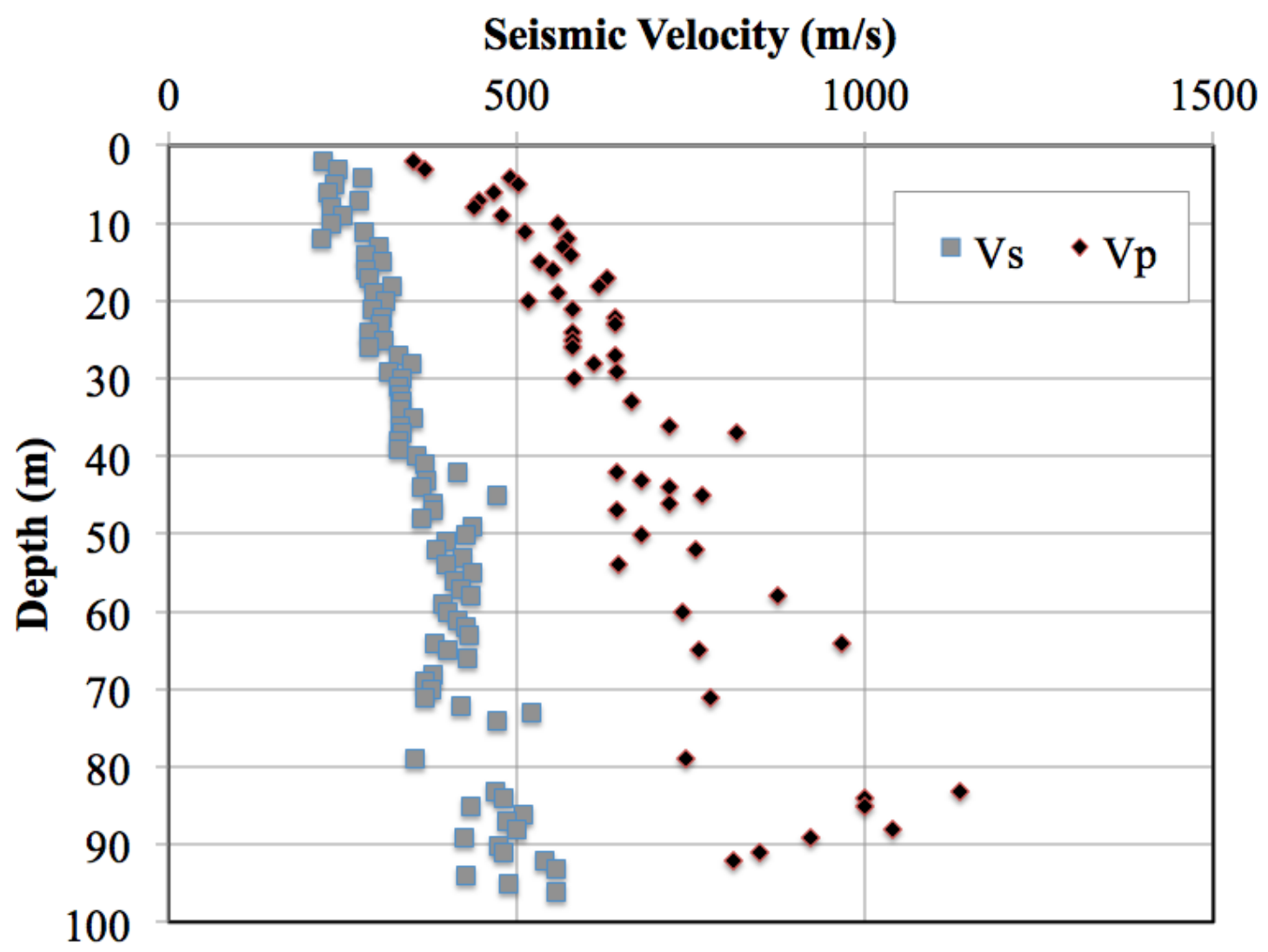

Figure 3 Typical seismic velocity profile in terms of compression $\left(\mathrm{V}_{\mathrm{p}}\right)$ and shear wave velocity $\left(\mathrm{V}_{\mathrm{s}}\right)$ measured using a SCPTu. 


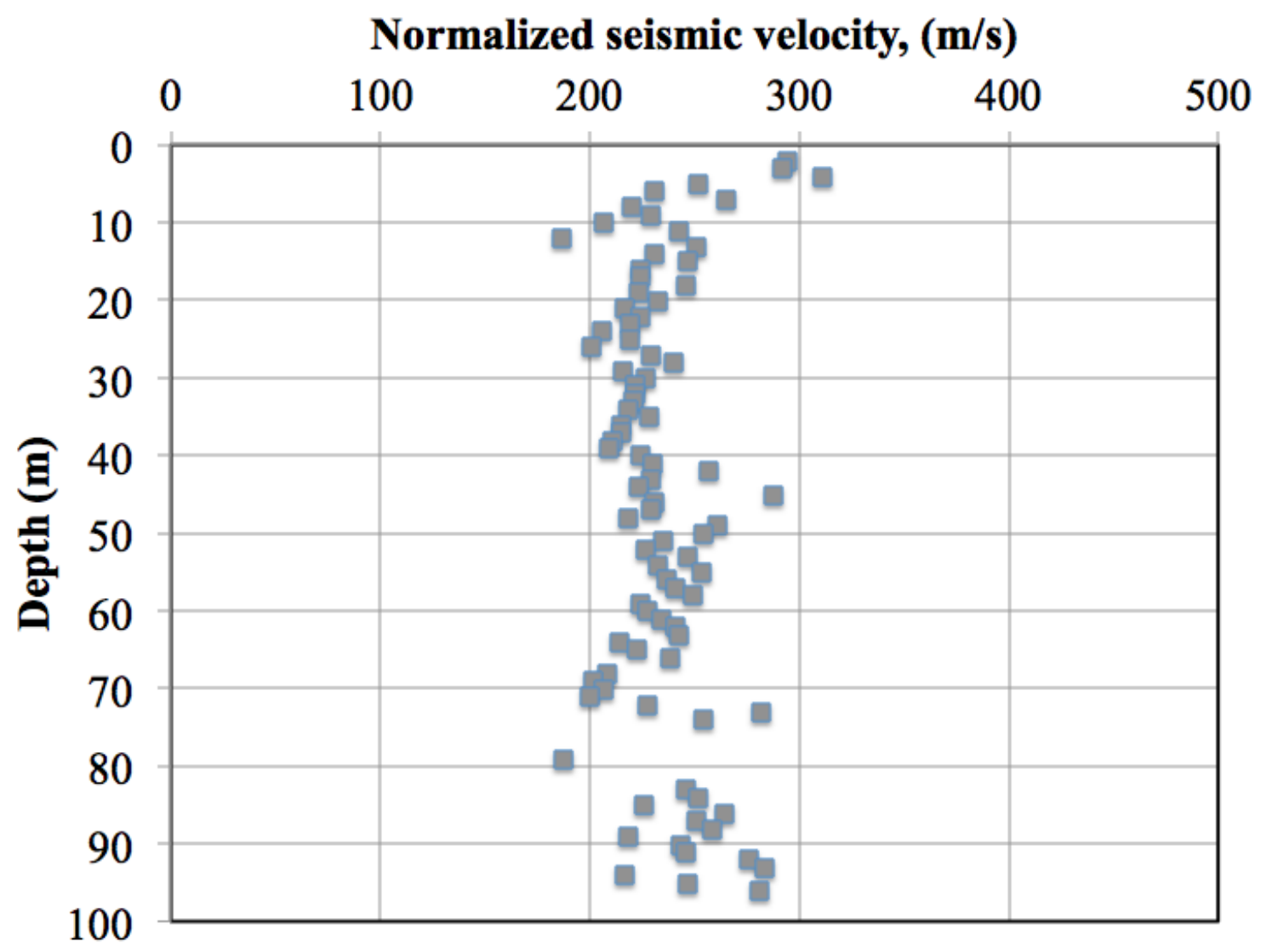

Figure 4 Typical normalized shear wave velocity, $\mathrm{V}_{\mathrm{s} 1}$ 


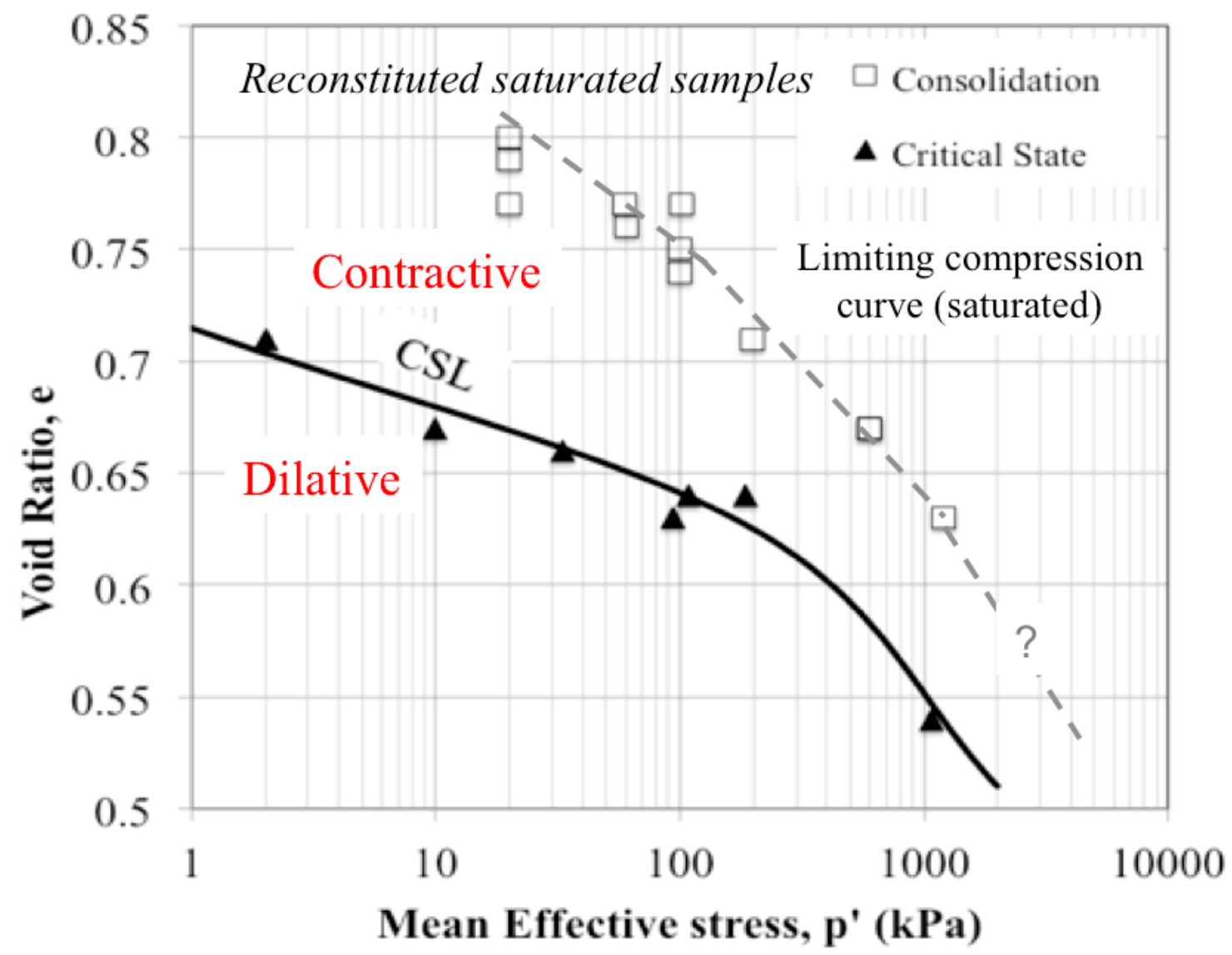

Figure 5 Summary of isotropically consolidated triaxial compression tests on saturated reconstituted loose samples showing Critical State Line (CSL) and Limiting Compression Curve (LCC). 


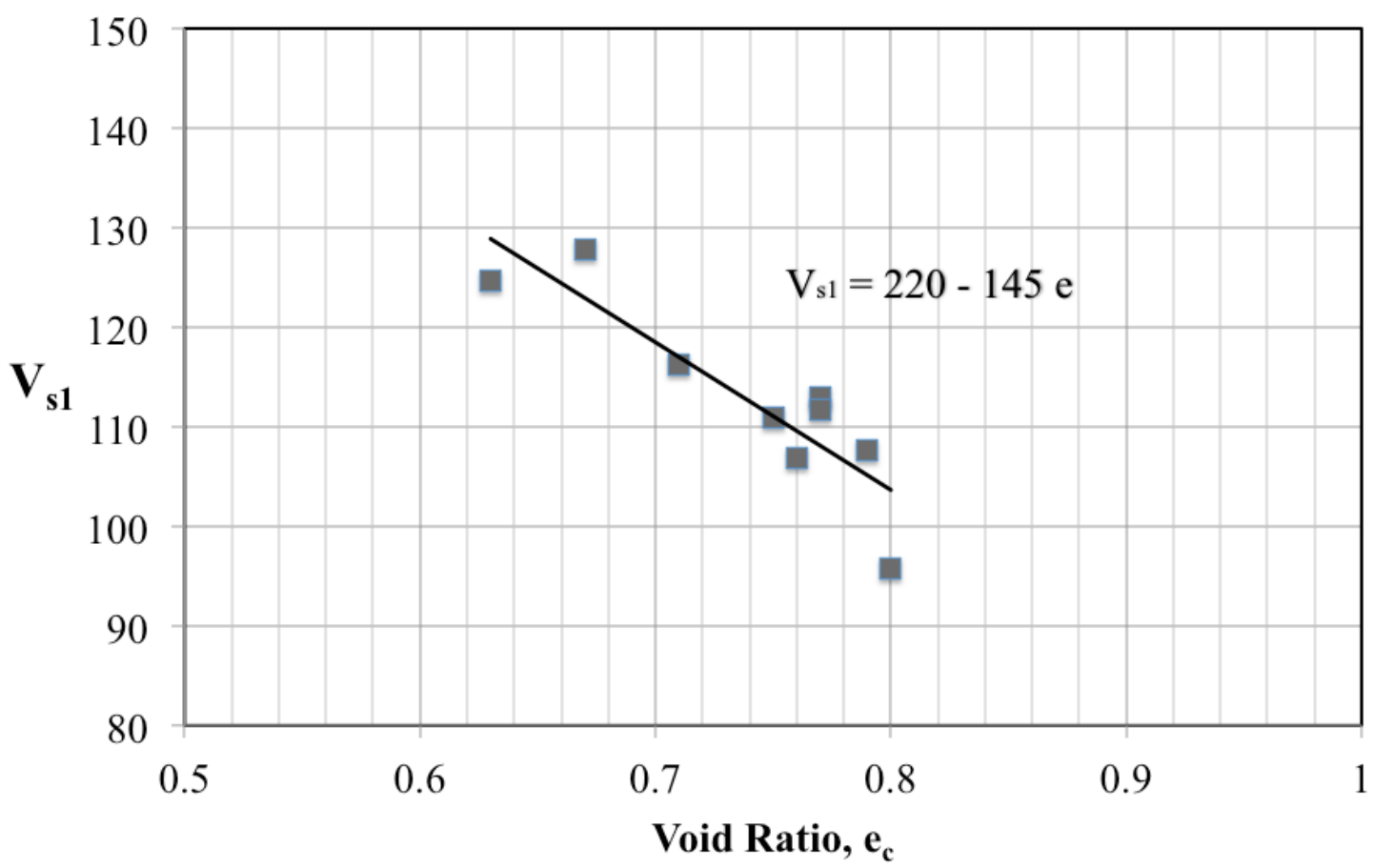

Figure 6 Normalized shear wave velocity $\left(\mathrm{V}_{\mathrm{s} 1}\right)$ as a function of void ratio at the end of consolidation $\left(\mathrm{e}_{\mathrm{c}}\right)$ for saturated samples 


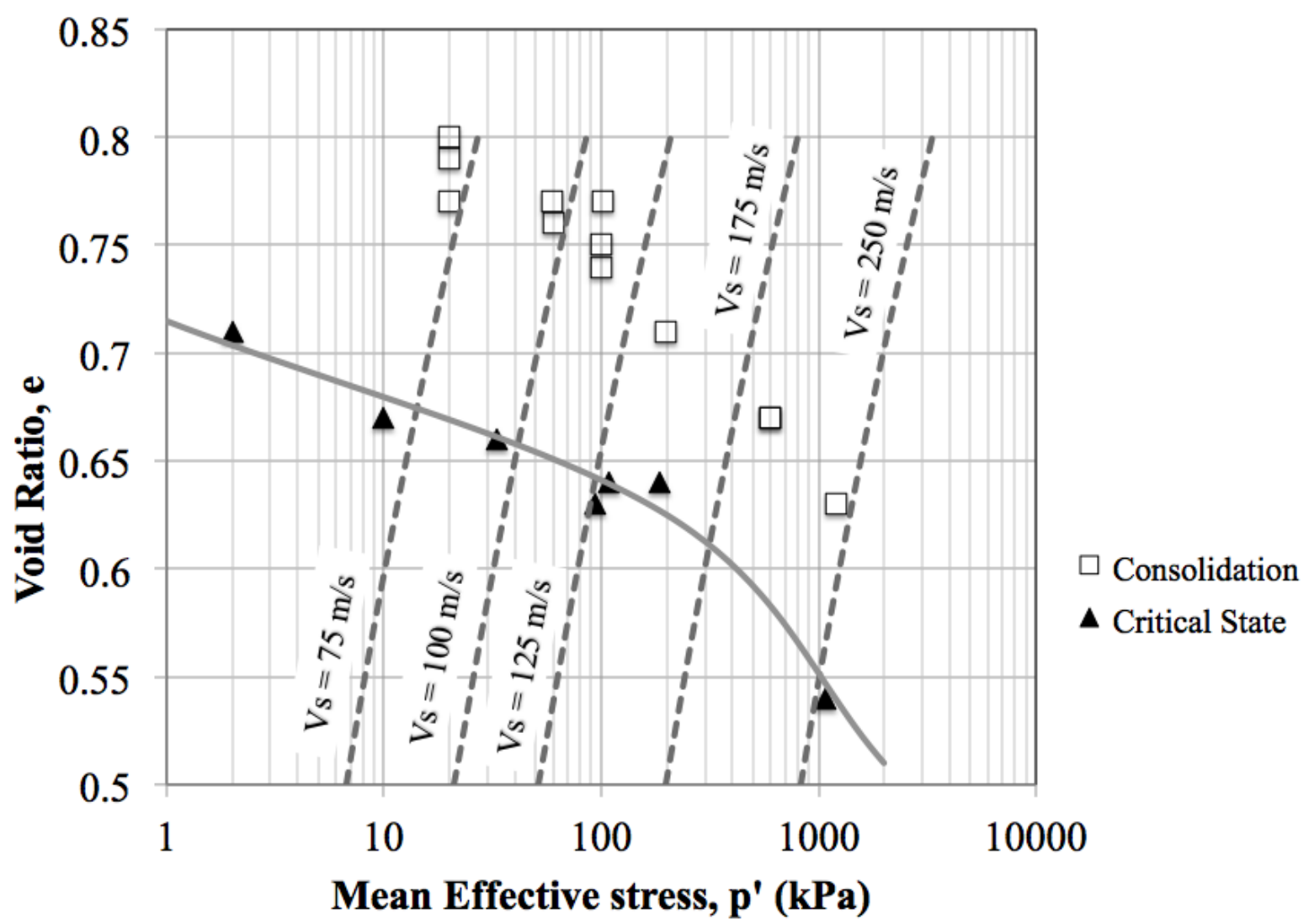

Figure 7 Summary of isotropically consolidated triaxial compression tests on saturated reconstituted tailings samples with contours of shear wave velocity $\left(\mathrm{V}_{\mathrm{s}}\right)$ 


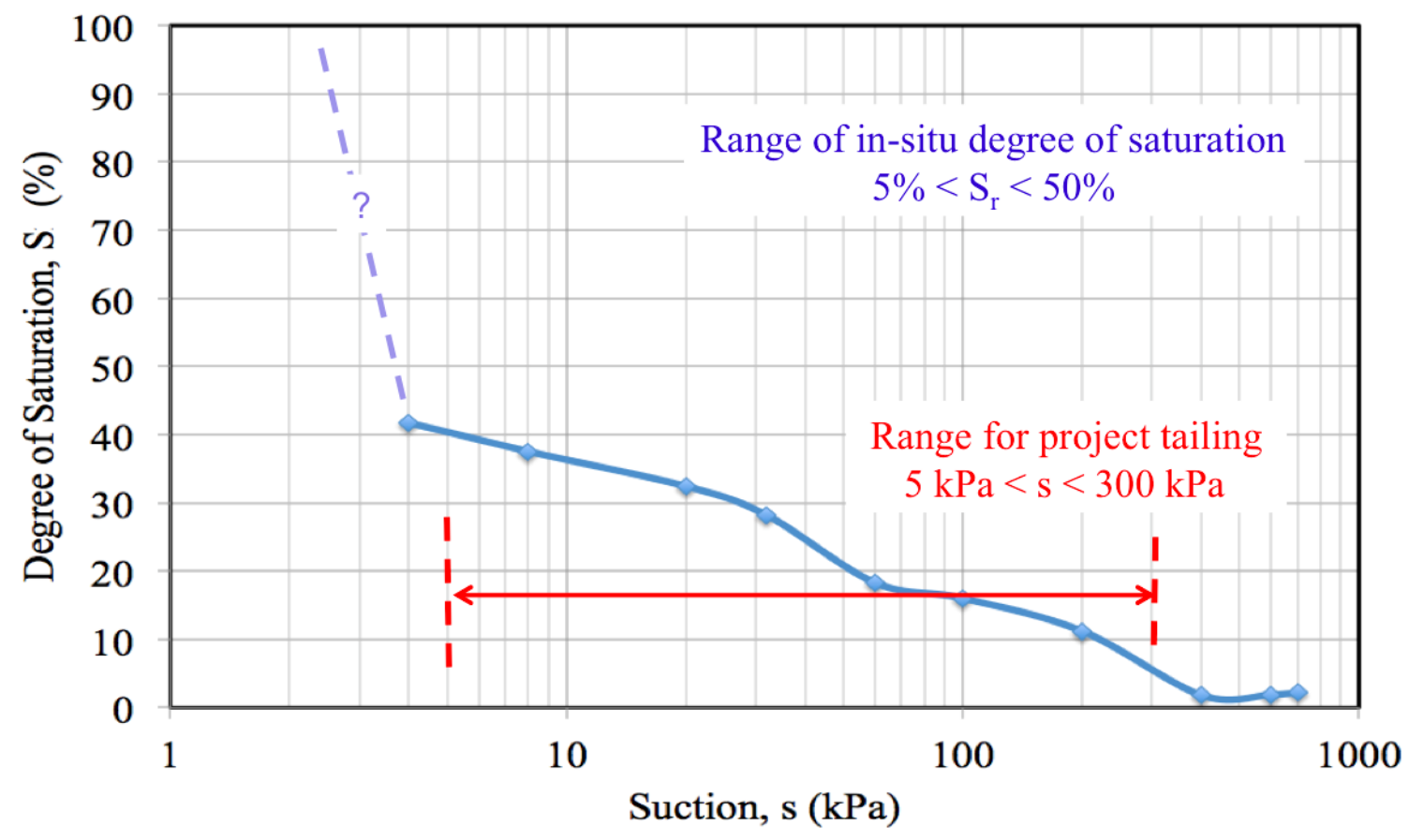

Figure $8 \quad$ SWCC in terms of degree of saturation versus matric suction for silty tailings 


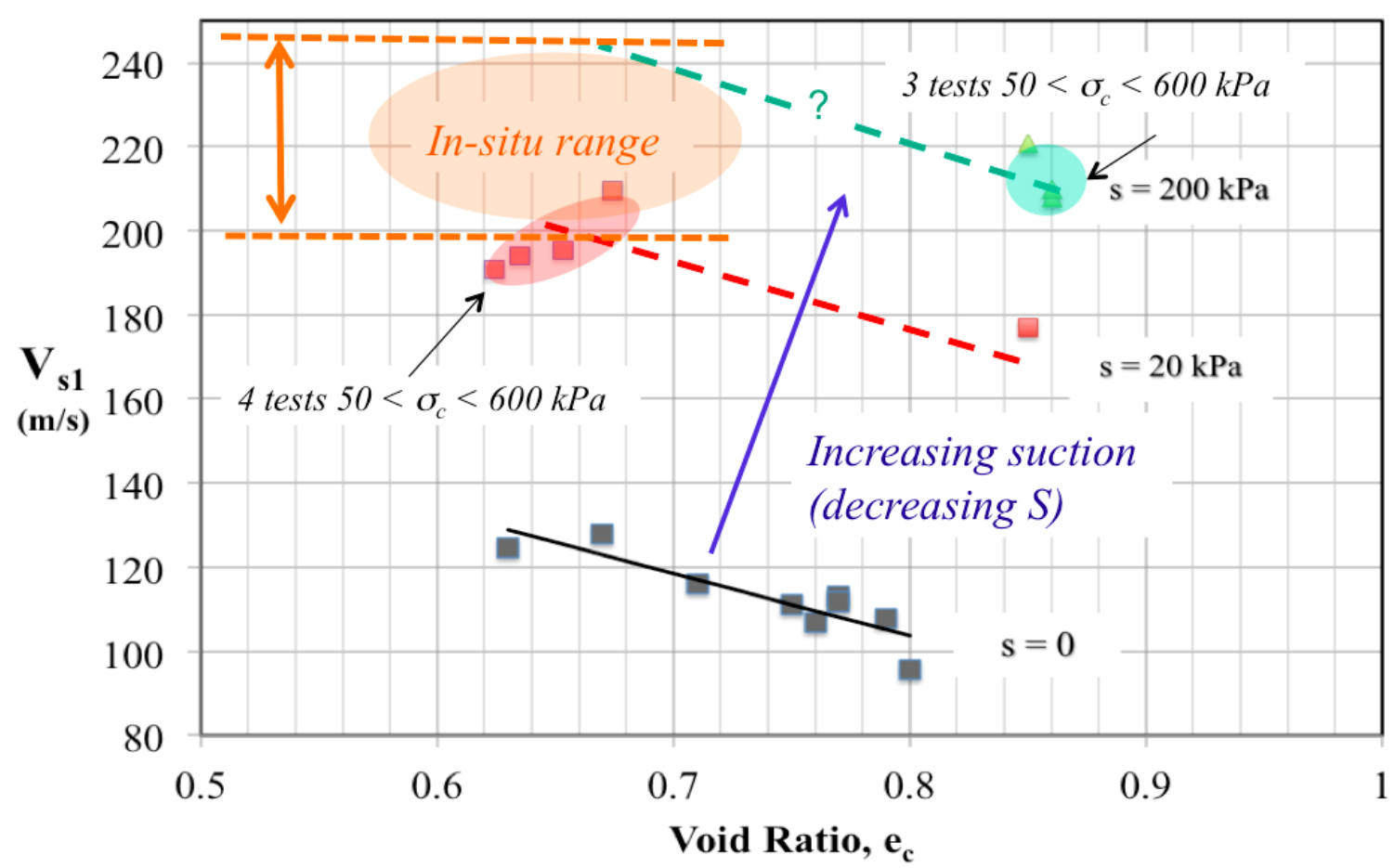

Figure 9 Normalized shear wave velocity $\left(\mathrm{V}_{\mathrm{s} 1}\right)$ as a function of void ratio at the end of consolidation $\left(\mathrm{e}_{\mathrm{c}}\right)$ for saturated $(\mathrm{s}=0)$ and unsaturated samples with suction of $\mathrm{s}=20$ and $200 \mathrm{kPa}$ of silty tailings 
CGJ - Characterization of unsaturated mine waste: a case history

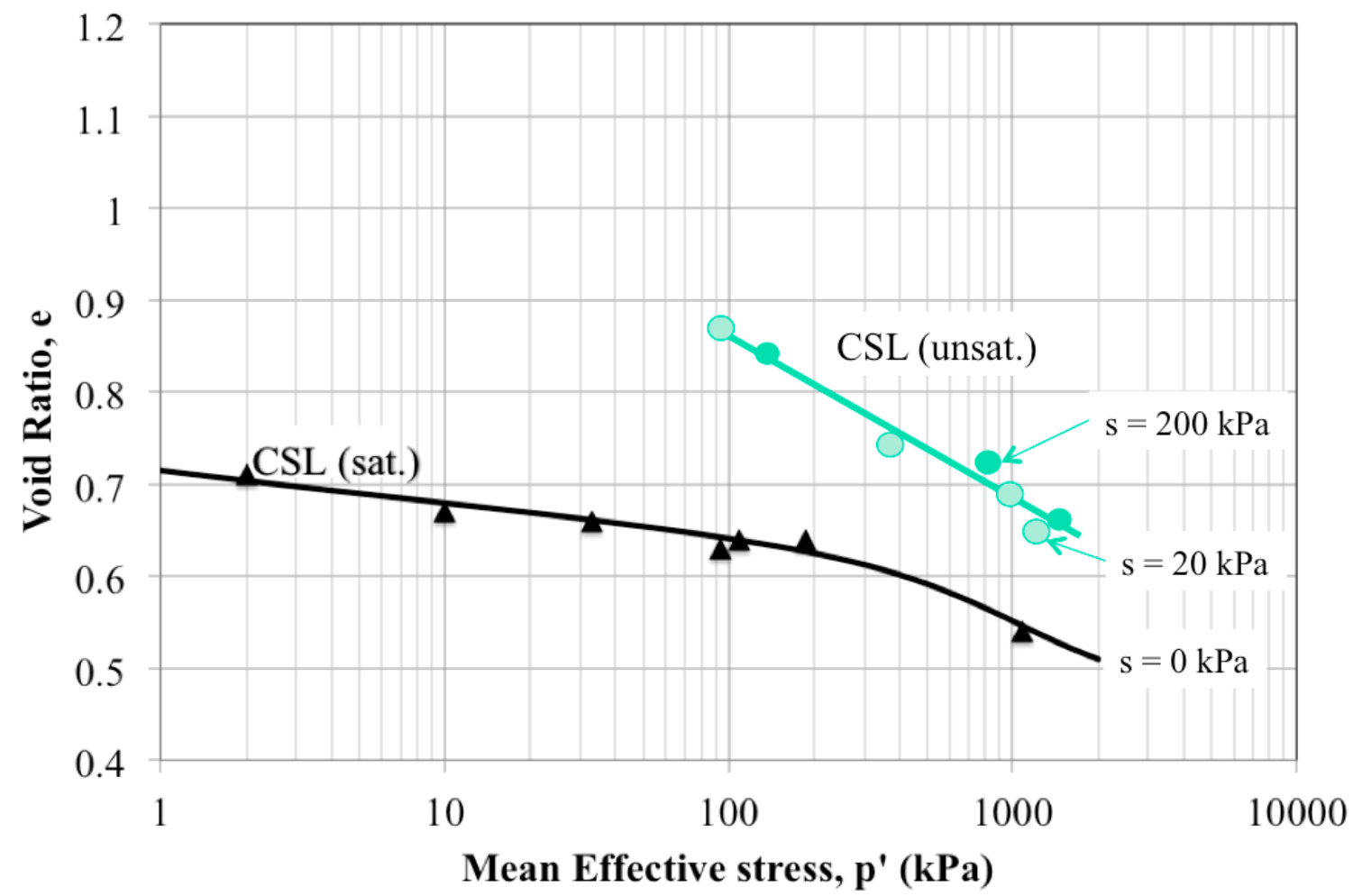

Figure $10 \quad$ Critical State Line (CSL) for both saturated $(\mathrm{s}=0)$ and unsaturated samples $(\mathrm{s}=20$ and $200 \mathrm{kPa})$ of silty tailings 


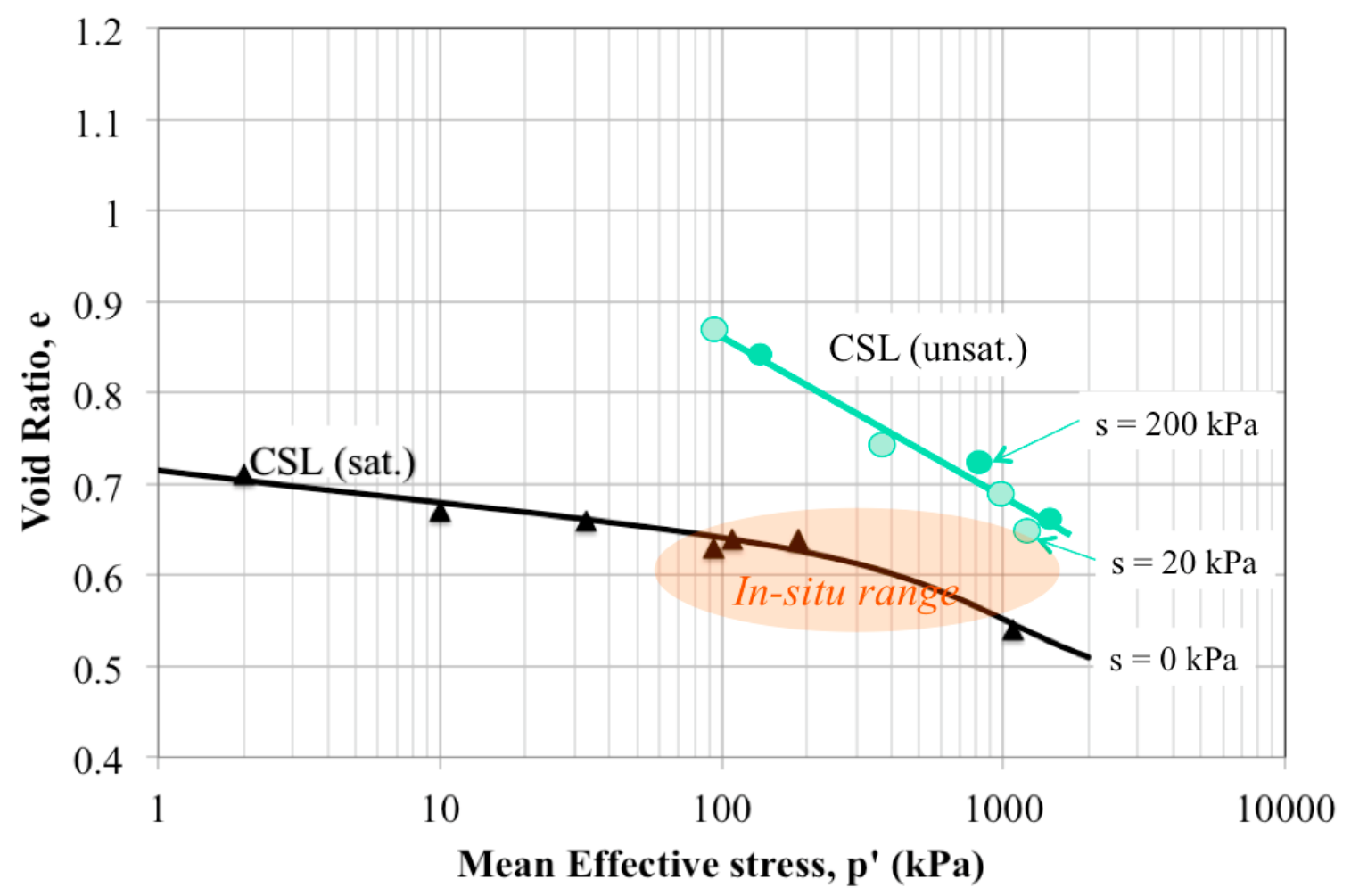

Figure 11 Critical State Line (CSL) for both saturated $(\mathrm{s}=0)$ and unsaturated samples ( $\mathrm{s}=20$ and $200 \mathrm{kPa}$ ) of silty tailings showing estimate range of in-situ void ratio and effective stress levels based on in-situ shear wave velocity measurements and laboratory tests on unsaturated samples 